\title{
PENINGKATAN PERILAKU PROSOSIAL PADA ANAK USIA 4-5 TAHUN MELALUI KEGIATAN OUTBOND FUN ESTAFET DI TK PGRI LANGKAP BURNEH BANGKALAN
}

\author{
Dewi Mayangsari \\ Evi Dwi Novita Sari \\ Nofiana Munaila \\ PGPAUD FIP Universitas Trunojoyo Madura \\ email:mayangsarie@gmail.com
}

\begin{abstract}
Abstrak: Peningkatan Perilaku Prososial Pada Anak Usia 4-5 Tahun Melalui Kegiatan Outbond Fun Estafet di TK PGRI Langkap Burneh Bangkalan. Perilaku prososial merupakan nilai penting dalam mengembangkan hubungan sosial dengan lingkungan masyarakat dimulai dengan belajar menyesuaikan diri dan bekerjasama dalam kegiatan bermain. Di TK PGRI Langkap, Burneh Bangkalan orang tua dan guru mengeluhkan perilaku prososial anak yang dirasa kurang. Salah satu strategi yang dipilih untuk mengembangkan aspek ini yaitu mengajak anak bermain diluar ruangan, mengadakan suatu kompetisi dan biasanya disebut Outbond. Kegiatan Outbond pada penelitian ini disebut Fun Outbond Esafet dilaksanakan berkelompok. Tujuan dari penelitian ini yaitu peneliti ingin mengetahui keefektifan kegiatan Outbond Fun Estafet di TK PGRI Langkap Burneh Bangkalan untuk meningkatkan perilaku prososial. Metode yang digunakan Penelitian Tindakan Kelas. Hasil dari penelitian ini, kegiatan Outbound Fun Estafet dapat meningkatkan kemampuan prososial anak usia dini 4-5 tahun di TK PGRI Langkap, Burneh Bangkalan. Kemampuan prososial anak meningkat dari $31 \%$ menjadi 86,20\% selama dua siklus.
\end{abstract}

Kata kunci: Perilaku Prososial, Anak Usia 4-5 Tahun, Outbond

\begin{abstract}
Improvement of Prosocial Behavior in Children Ages 4-5 Years Through Outbound Fun Fun Activities in TK PGRI Langkap Burneh Bangkalan. Prosocial behavior is an important value in developing social relationships with the community environment starting with learning to adjust and cooperate in play activities. In Kindergarten PGRI Langkap, Burneh Bangkalan parents and teachers complain about the child's prosocial behavior is perceived as lacking. One strategy chosen to develop this aspect is to invite children to play outside the room, held a competition and usually called Outbond. Outbond activities in this research called Fun Outbond Esafet implemented in groups. The purpose of this study is the researchers wanted to know the effectiveness of activities Outbound Fun Relay in Kindergarten PGRI Langkap Burneh Bangkalan to improve prosocial behavior. The methods used Classroom Action Research. The results of this research, Outbound Fun Relay activities can improve the prosocial ability of children aged 4-5 years in Kindergarten PGRI Langkap, Burneh Bangkalan. The child's prosocial ability increased from $31 \%$ to $86.20 \%$ over two cycles.
\end{abstract}

Keywords: Prosocial Behavior, Children Aged 4-5 Years, Outbound 
Anak usia dini merupakan saat seseorang mengalami perkembangan dan pertumbuhan yang sangat pesat dalam kehidupannya. Perkembangan dan pertumbuhan pada anak usia dini membutuhkan beragam stimulasi yang dapat membantunya untuk berkembang dengan baik sesuai dengan kebutuhan dan potensinya. Saat ini jumlah anak usia dini di Negara kita semakin meningkat dan berdasarkan data yang diperoleh pada tahun 2012 diperkirakan hampir 23.352.721 data tersebut menunjukkan jumlah anak-anak usia dini mengalami peningkatan yang signifikan dan membutuhkan bimbingan untuk mencapai perkembangan yang optimal (www.depkes.go.id). Perkembangan yang optimal bagi anak ketika mengalami masa pertumbuhan fisik, perkembangan kognitif, motorik, emosi, bahasa serta sosial merupakan perkembangan yang selayaknya dicapai oleh setiap anak, dan untuk mencapainya dibutuhkanlah suatu pendidikan dan pembelajaran yang dapat menstimulasi anak untuk mencapai perkembangan dan pertumbuhannya.

Mengingat salah satu aspek perkembangan yang sangat penting dalam diri anak yakni aspek sosial, yang ada kaitannya tentu dengan hubungan interaksi anak dengan dengan lingkungan disekitarnya. Hal tersebut merupakan aspek penting yang membedakan manusia dengan makhluk lain adalah saling tolong menolong, kerjasama, dan memiliki kepedulian antar sesama manusia (Knafo, 2006). Dalam perkembangan sosial terdapat perilaku prososial dan anti sosial, pada kajian yang akan dibahas adalah mengenai perkembangan prososial. Sejak usia 2-6 tahun, anak belajar melakukan hubungan sosial dan bergaul dengan orang-orang dilingkungan rumah terutama dengan anak-anak yang usianya sebaya, mereka akan belajar menyesuaikan diri dan bekerja sama dalam kegiatan bermain. Perilaku prososial merupakan nilai penting dalam mengembangkan hubungan sosial dengan lingkungan masyarakat, namun disisi lain lingkungan cenderung mempengaruhi perilaku prososial anak usia dini. Menurut Hurlock (1978) perilaku prososial pada anak muncul sejak usia 2 hingga 6 tahun, anak belajar melakukan hubungan sosial dan bergaul dengan orang di luar lingkungan rumah yang sebaya (Hurlock, 1978). Mereka melakukan perilaku prososial dimulai dengan belajar menyesuaikan diri dan bekerjasama dalam kegiatan bermain dan sejak usia 3 atau 4 tahun perilaku prososial semakin meningkat karena pada usia itu anak mulai bermain dengan kelompoknya. Peningkatan perilaku prososial cenderung lebih dominan pada masa anakanak awal, hal ini disebabkan oleh pengalaman sosial yang semakin bertambah.

Orang tua sering mengeluhkan sang anak tidak mau menuruti kata-kata ibunya, seperti ketika anak mereka tidak mau berbagi mainan dengan teman atau adiknya. Kondisi seperti ini sudah jelas menggambarkan bahwa minimnya perilaku sosial yang dimiliki oleh anak, jika hal ini dibiarkan berkelanjutan sampai anak memasuki masa remaja maka dapat dimungkinkan anak akan di acuhkan oleh lingkungan masyarakat bahkan keberadaannya akan tergusur karena sikap antisosialnya. Pengembangan perilaku prososial merupakan salah satu jenis kompetensi sosial yang penting untuk dimiliki anak usia dini, dimana seorang anak mampu memahami perspektif orang lain.

Hasil wawancara dengan guru kelas yang dilakukan pada 14 April 2017, perilaku prososial yang kurang tampak adalah penghargaan anak kepada teman lainnya. Hal ini berwujud sebagian anak kurang antusias untuk bertepuk tangan ketika ada salah satu teman yang dapat menjawab pertanyaan secara benar dari guru.Ada juga anak yang tidak mau bermain dengan temannya karena mereka mengakui tidak begitu dekat dari awal. Perlunya pihak sekolah untuk mengatasi permasalahan tersebut dalam mengembangkan kemampuan prososial anak diperlukan proses pembelajaran yang efektif, menyenangkan, 
menarik dan bermakna bagi anak. Proses pembelajaran tersebut dipengaruhi oleh berbagai unsur, antara lain guru yang memahami secara utuh hakikat, sifat karakteristik anak, metode pembelajaran yang berpusat pada kegiatan anak, sarana kegiatan anak yang memadai, ketersediaannya berbagai sumber dan media belajar yang menarik dan mendorong anak untuk belajar.

Hasil kondisi dilapangan anak yang berusia 4-5 tahun dapat dilihat dari jumlah anak dikelas ada 25 anak dan hampir 15 anak mengalami degradasi perilaku prososial tersebut maka Salah satu strategi yang dipilih untuk mengembangkan aspek ini adalah mengajak anak untuk bermain diluar ruangan/outdoor dengan mengadakan suatu kompetisi dan biasanya kita sebut Outbond. Outbound merupakan metode pelatihan untuk pengembangan diri (personal development) dan tim (team development) dalam proses mencari pengalaman melalui kegiatan di alam terbuka. Kali ini kegiatan Outbond akan dilaksanakan secara berkelompok agar jiwa kooperatif dalam diri anak bisa terstimulus. Outbond Fun Estafet ini akan dilaksanakan untuk mengajarkan anak saling bekerja sama dengan teman, maupun orang lain.

Berdasarkan uraian yang sudah dijelaskan diatas maka perlu dikaji secara mendalam mengenai perilaku prososial yang kini sudah sangat minim dilakukan oleh anak usia dini, maka peneliti ingin melakukan penelitian mengenai bagaimana cara Meningkatkan Perilaku Prososial Pada Anak Usia 4-5 Tahun Melalui Kegiatan Outbond Fun Estafet di TK PGRI Langkap Burneh Bangkalan.

\section{Konsep Penelitian Tindakan}

\author{
Penelitian Tindakan Kelas dalam \\ bahasa Inggris adalah classroom Action \\ Research (CAR). Menurut Hopkins (1992) \\ PTK adalah penelitian yang dirancang untuk \\ membantu guru dalam mengetahui apa yang \\ sedang terjadi di dalam kelasnya, dan
}

menggunakan informasi itu untuk membuat keputusan yang tepat untuk kesempatan berikutnya (Arifin, 2013). Metode yang digunakan meliputi kualitatif atau kuantitatif, deskriptif atau eksperimental. Penelitian tindakan kelas dilakukan oleh guru untuk meningkatkan kinerja atau untuk menguji asumsi-asumsi teori pendidikan dan praktiknya.

Suatu peristiwa sosial dengan tujuan untuk meningkatkan kualiatas tindakan di dalamnya, dimana dalam proses tersebut mencakup kegiatan yang menimbulkan hubungan antara evaluasi diri dengan peningkatan profesional, merupakan PTK menurut John Elliot. Sedangkan menurut Arikunto pengertian PTK yakni gabungan pengertian dari kata "penelitian, tindakan dan kelas". Penelitian adalah kegiatan mengamati suatu objek, dengan menggunakan kaidah metodologi tertentu untuk mendapatkan data yang bermanfaat bagi peneliti dan dan orang lain demi kepentingan bersama. Selanjutnya tindakan adalah suatu perlakuan yang sengaja diterapkan kepada objek dengan tujuan tertentu yang dalam penerapannya dirangkai menjadi beberapa periode atau siklus. Dan kelas adalah tempat di mana sekolompok siswa belajar bersama dari seorang guru yang sama dalam periode yang sama (Sanjaya, 2010).

Dapat disimpulkan bahwa penelitian tindakan kelas (PTK) adalah suatu pengamatan yang menerapkan aturan sesuai dengan metodologi penelitian yang dilakukan dalam beberapa periode atau siklus. Berdasarkan jumlah dan sifat perilaku para anggotanya, PTK dapat berbentuk individual dan kolaboratif, yang dapat disebut PTK individual dan PTK kolaboratif. PTK individual seorang guru melaksanakan PTK di kelasnya sendiri atau kelas orang lain, sedang dalam PTK kolaboratif beberapa orang guru secara sinergis melaksanakan PTK di kelas masing-masing dan diantara anggota melakukan kunjungan antar kelas. 
Berdasarkan pada pengertian di atas, menurut Arifin (2013) PTK memiliki karakterlistik tersendiri sebagai pembeda dengan penelitian-penelitian lainya. Adapun beberapa karakter tersebut adalah:

1 Masalah yang diteliti harus cemerlang, dengan demikian dalam rancangan penelitian harus ada uraian tentang keunggulan/kecemerlangan tindakan yang dilakukan dibandingkan dengan yang dilakukan sebelumnya.

2 Berpusat pada proses, agar guru mengetahui apakah proses yang terjadi sudah baik apa belum, guru menggunakan format pengamatan yang terdiri dari butir-butir yang rinci.

3 Adanya inkuiri reflaktif, PTK dikatakan memiliki ciri inkuiri reflektif, karena dengan tindakan yang dilakukan, kemudian dilakukan pengamatan dan refleksi.

4 Adanya kolaborasi, sesuai konsep dasarnya selain guru merencanakan dan melaksanakan tindakan secara bersamaan guru juga harus melakuakan pengamatan. Dengan demikian sangat dibutukan mitra yang dapat membantu guru dalam melaksanakan PTK.

5 Adanya refleksi, sesuai ide dasarnya, PTK tidak dapat terlepas dari kegiatan refleksi. Karena tindakan yang dilaksanakan dan direncanakan, pada dasarnya adalah upaya mencapai sesuatu yang diharapkan. Maka upaya ini perlu dilihat tingkat keberhasilannya maupun kualitas proses yang dijalankan.

Berdasarkan pendapat para ahli, adapun Tujuan Penelitian Tindakan Kelas dapat dirumuskan sebagai berikut:

1 Memperbaiki dan meningkatkan mutu praktik pembelajaran yang dilaksanakan guru demi tercapainya tujuan pembelajaran.
2 Memperbaiki dan meningkatkan kinerjakinerja pembelajaran yang dilaksanakan oleh guru.

3 Mengidentifikasi, menemukan solusi, dan mengatasi masalah pembelajaran di kelas agar pembelajaran bermutu.

4 Meningkatkan dan memperkuat kemampuan guru dalam memecahkan masalah-masalah pembelajaran dan membuat keputusan yang tepat bagi siswa dan kelas yang diajarnya.

5 Mengeksplorasi dan membuahkan kreasi-kreasi dan inovasi-inovasi pembelajaran (misalnya, pendekatan, metode, strategi dan media) yang dapat dilakukan oleh guru demi peningkatan mutu proses dan hasil pembelajaran.

PTK mempunyai karaktaristik yang berbeda dengan penelitian yang lain. PTK merupakan penelitian kualitatif meski data yang diperoleh dapat berupa data kuantitatif.

Penelitian tindakan dilakukan dalam suatu siklus (putaran) tertentu. Setiap siklus terdiri dari sejumlah langkah yang harus dikerjakan peneliti. Ada beberapa model rancangan yang dikemukakan para pakar. Berikut beberapa model PTK yang sering digunakan dalan dunia pendidikan, yaitu (1) model Kurt Lewin, (2) model Kemmis \& Taggart, dan (3) model John Elliot (Arikunto, 2008).

$1 \quad$ Model Kurt Lewin

Rancangan model Kurt Lewin merupakan model dasar yang kemudian dikembangkan oleh ahli-ahli lain. Penelitian tindakan, menurut Kurt Lewin, terdiri dari empat komponen kegiatan yang dipandang sebagai satu siklus, yaitu: perencanaan (planning), tindakan (acting), pengamatan (observing), dan refleksi (reflecting). 
Awalnya proses penelitian dimulai dari perencanaan, namun karena ke empat komponen tersebut berfungsi dalam suatu kegiatan yang berupa siklus, maka untuk selanjutnya masingmasing berperan secara berkesinambungan.

2 Model Kemmis \& Taggart

Model Kemmis \& Taggart, adapun pengertiannya dari Rancangan Penelitian Tindakan Model Kemmis \& McTaggart adalah pengembangan lebih lanjut dari model Kurt Lewin. Secara mendasar tidak ada perbedaan yang prinsip antara keduanya. Model ini banyak dipakai karena sederhana dan mudah dipahami. Rancangan Kemmis \& Taggart dapat mencakup sejumlah siklus, masing-masing terdiri dari tahaptahap: perencanaan (plan), pelaksanaan dan pengamatan (act \& observe), dan refleksi (reflect). Tahapan-tahapan ini berlangsung secara berulang-ulang, sampai tujuan penelitian tercapai.

Langkah pertama pada setiap siklus adalah penyusunan rencana tindakan. Tahapan berikutnya pelaksanaan dan sekaligus pengamatan terhadap pelaksanaan tindakan. Hasil pengamatan kemudian dievaluasi dalam bentuk refleksi. Apabila hasil refleksi siklus pertama menunjukkan bahwa pelaksanaan tindakan belum memberikan hasil sebagaimana diharapkan, maka berikutnya disusun lagi rencana untuk dilaksanakan pada siklus kedua. Demikian seterusnya sampai hasil yang dinginkan benarbenar tercapai.

Model John Elliot

Model PTK dari John Elliot ini lebih rinci jika dibandingkan dengan model Kurt Lewin dan model KemmisMc Taggart. Dikatakan demikian, karena di dalam setiap siklus terdiri dari beberapa aksi, yaitu antara tiga sampai lima aksi (tindakan). Sementara itu, setiap tindakan kemungkinan terdiri dari beberapa langkah yang terealisasi dalam bentuk kegiatan belajar-mengajar.

\section{Hakikat Anak Usia Dini}

Anak usia dini adalah anak yang baru dilahirkan sampai usia 6 tahun, usia ini merupakan usia yang sangat menentukan dalam pembentukan karakter dan kepribadian anak (Sujiani, 2012). Usia dini merupakan usia di mana anak mengalami pertumbuhan dan perkembangan yang pesat. Usia dini disebut sebagai usia emas (golden age). Makanan yang bergizi yang seimbang serta stimulasi yang intensif sangat dibutuhkan untuk pertumbuhan dan perkembangan tersebut. Maksud dari anak usia dini atau anak prasekolah adalah mereka yang berusia antara 0 sampai 6 tahun. Mereka biasanya mengikuti program prasekolah atau kindergarten. Sedangkan di Indonesia umumnya mereka mengikuti program tempat penitipan anak dan kelompok bermain (play group).

Pendidikan anak usia dini merupakan salah satu bentuk penyelenggaraan pendidikan, yang menitikberatkan pada peletak dasar pertama kearah pertumbuhan dan perkembangan fisik (koordinasi motorik kasar dan halus), kecerdasan (daya pikir, daya cipta, kecerdasan emosi, kecerdasan spiritual), sosio emosional (sikap perilaku dan beragama), bahasa dan komunikasi, sesuai dengan tahaptahap yang dilalui oleh anak usia dini. Setiap aspek perkembangannya anak perlu mendapat dorongan atau bantuan yang dapat membantu anak dalam tingkat pencapaian perkembangan diusianya tersebut (Sujiani, 2012). Selain itu anak usia dini merupakan masa yang cemerlang untuk dilakukan dan diberikan pendidikan. Lain halnya bahwa anak usia 3-6 tahun merupakan periode sensitif atau masa peka terhadap anak, yaitu suatu periode dimana suatu fungsi tertentu perlu dirangsang, 
sehingga tidak terhambat perkembangannya (Hurlock, 2006).

Pembelajaran bagi anak usia dini adalah belajar sambil bermain. Bagi anak bermain adalah kegiatan yang serius namun mengasikkan, melalui bermain semua aspek perkembangan anak dapat ditingkatkan (Sujiani, 2012). Melalui bermain juga anak anak dapat berekspresi dan bereksplorasi untuk memperkuat hal-hal yang sudah diketahui dan menemukan hal-hal baru, dimana anak akan menyatakan jati dirinya, bukan saja fantasinya, tetapi juga keaktifannya.

Menurut Masitoh (2005) ada berbagai kajian tentang hakikat anak usia dini, khususnya anak PAUD diantaranya oleh Bredecam dkk yaitu anak bersifat unik, anak mengekspresikan perilakunya secara relatif spontan, anak bersifat aktif dan enerjik, egosentris, memiliki rasa ingin tahu yang kuat dan antusias terhadap banyak hal, bersifat eksploratif dan berjiwa petualang, umumnya kaya dengan fantasi, masih mudah frustasi, masih kurang pertimbangan dalam bertindak, memiliki daya perhatian yang pendek, masa anak merupakan masa belajar yang paling potensial, serta anak semakin menunjukan minat terhadap teman

\section{Prinsip-prinsip AUD}

a. Prinsip-prinsip perkembangan anak usia dini berbeda dengan pinsipprinsip perkembangan fase kanakkanak akhir dan seterusnya. adapun prinsip-prinsip perkembangan anak usia dini menurut Bredekamp dan Coople adalah sebagai berikut (Hurlock, 1978):

b. Perkembangan aspek fisik, sosial, emosional, kognitif anak saling berkaitan dan saling mempengaruhi satu sama lain.

c. Perkembangan fisik/motorik, emosi, sosial, bahasa, dan kognitif anak terjadi dalam suatu urutan tertentu yang relatif dapat diramalkan. d. Perkembangan berlangsung dalam rentang yang bervariasi antar anak dan antar bidang pengembangan dari masing-masing fungsi.

e. Pengalaman awal anak memiliki pengaruh kumulatif dan tertunda terhadap perkembangan anak.

f. Perkembangan anak berlangsung kearah yang makin kompleks, khusus, terorganisasi dan terinternalisasi.

g. Perkembangan dan cara belajar anak terjadi dan dipengaruhi oleh konteks sosial budaya yang majemuk

h. Anak adalah pembelajar yang aktif, yang berusaha membangun pemahamannya tentang lingkungan sekitar dari pengalaman fisik, sosial, dan pengetahuan yang diperolehnya.

i. Perkembangan dan belajar merupakan interaksi kematangan biologis dan lingkungan fisik maupun lingkungan sosial.

j. Bermain merupakan sarana penting bagi perkembangan sosial, emosional, dan kognitif anak serta menggambarkan perkembangan anak.

k. Perkembangan akan mengalami percepatan bila anak berkesempatan untuk mempraktikan berbagai keterampilan yang diperoleh dan mengalami tantangan setingkat lebih tinggi dari hal-hal yang dikuasainya.

1. Anak memiliki modallitas beragam (ada tipe visual, auditif, kinestetik, atau gabungan dari tipe-tipe itu) untuk mengetahui sesuatu sehingga dapat belajar hal yang berbeda dalam memperlihatkan hal-hal yang diketahuinya.

m. Kondisi terbaik anak untuk berkembang dan belajar adalah dalam komunitas yang menghargainya, memenuhi kebutuhan fisiknya, dan aman secara fisik dan fisiologis. 
Kegiatan Outbond

Outbound adalah kegiatan di alam terbuka. Outbound juga dapat memacu semangat belajar dan merupakan sarana penambah wawasan pengetahuan yang di dapat dari serangkaian pengalaman petualang. Outbound merupakan perpaduan antara permainan sederhana, permainan ketangkasan dan olah raga, serta petualangan (Umar, 2011). Hal itu yang akhirnya membentuk adanya unsur-unsur ketangkasan dan kebersamaan serta keberanian dalam memecahkan masalah. Seperti halnya Iwan menegaskan bahwa "permainan yang disajikan dalam outbound memang telah disusun sedemikian rupa, sehingga bukan hanya psikomotorik (fisik) peserta yang tersentuh, tapi juga afeksi (emosi) dan kognisi (kemampuan berpikir). Shoimin (2014) menjelaskan bahwa outbond adalah sebuah cara untuk menggali diri sendiri dalam suasana menyenangkan dan tempat penuh tantangan yang dapat menggali dan mengembangankan potensi, memberikan tantangan dalam kegiatan untuk mengembangkan kemampuan seorang anak untuk masa depannya. Outbond juga dapat dikatakan sebagai kegiatan di luar ruangan yang bersifat petualangan danpenuh tantangan serta merupakan kegiatan belajar sambil bermain maupun sebaliknya (Widiasworo, 2017).

Aktifitas outbound dapat menjaga otak agar terus bergerak dalam melaksanakan kegiatan. Adrianus dan Yufiarti (dalam Umar, 2011) mengatakan bahwa "di dalam outbound terdapat unsur-unsur pengembangan kreativitas, komunikasi, mendengarkan efektif, kerjasama, motivasi diri, kompetisi, problem solving dan percaya diri". Kegiatan outbound mempunyai arti kegiatan di luar ruangan tersebut mengandung unsur permainan, edukasi, serta rekreasi. Melalui permainanpermainan ringan yang menarik, peserta didik dihadapkan pada suatu tantangan untuk dipecahkan secara bersama-sama dengan sejenak melepaskan atribut masing-masing. Sehingga diharapkan tercipta suasana keakraban, kebersamaan serta kerjasama tim yang nantinya bermanfaat dalam mengatasi permasalahan yang lebih besar.

Outbound sebagai salah satu bentuk perubahan model pembelajaran pendidikan non formal merupakan contoh dari evolusi dan reformasi tenaga pendidik dan kependidikan, dalam kegiatan tersebut terdapat unsur-unsur yang akan berpengaruh terhadap rasa percaya diri seorang pemimpin yang tangguh, kerjasama tim yang solid dan pengembangan rasa percaya diri (Umar, 2011). Salah satu metode pembelajaran yang efektif adalah melalui aktivitas outbound yang melibatkan kegiatan olah fisik atau permainan. Cara ini cukup efektif untuk memperlengkapi para pimpinan atau manajemen segala lini, dengan aktivitas pembangunan tim dan karakter (character and teamworkbuilding) dan pengalaman kegiatan outdor yang bersifat mempertajam potensi kepemimpinan.

Pengalaman dalam kegiatan outbound memberikan masukan yang positif dalam perkembangan kedewasaan seseorang. Pengalaman itu mulai dari pembentukan kelompok. Kemudian setiap kelompok akan menghadapi bagaimana cara berkerja sama. Bersama-sama mengambil keputusan dan keberanian untuk mengambil risiko.

Kegiatan outbond dapat dilakukan mulai dari tingkat taman kanak-kanak hingga perguruan tinggi. Banyak variasi outbond, mulai dari permainan, 
pembelajaran, petulangan, dan lain-lain menyesuaikan tujuan diadakan outbond (Widiasworo, 2017).

\section{Perilaku Prososial}

Perilaku prososial menurut William, yaitu perilaku yang memiliki intense untuk mengubah keadaan fisik atau psikologis penerima bantuan dari kurang baik menjadi lebih baik, dalam arti secara material maupun psikologis (Dayaksini \& Hudaniah, 2003). Menurut Bartal mengartikan bahwa tingkah laku prososial atau tingkah laku yang menimbulkan konsekuensi positif bagi kesejahteraan fisik maupun psikis orang lain. Tingkah laku ini dilakukan secara sukarela (voluntary) dan menguntungkan (benefit) orang lain tanpa anti sipasi reward eksternal, yang meliputi menolong (helping), membantu (aiding), membagi (sharing), dan menyumbang (donating Lebih jauh lagi, pengertian perilaku prososial mencakup tindakan-tindakan sharing (membagi), cooperative (kerjasama), donating (menyumbang), helping (menolong), honesty (kejujuran), generosity (kedermawanan) serta mempertimbangkan hak dan kesejahteraan orang lain.

Penjelasan di atas dapat dirumuskan indikator perilaku prososial yang terdiri atas delapan komponen, yaitu :

1. Menolong (helping) Yaitu membantu, memberikan apa-apa yang berguna ketika dalam kesusahan.

2. Membagi (sharing) Yaitu memberikan sebagian dari apa yang kita punya, atau memberikan bagian kita pada orang lain.

3. Kerjasama (cooperative) Yaitu mengerjakan atau membagi tugas secara bersama-sama

4. Kejujuran (honesty) Yaitu mengatakan atau berbuat seperti apa yang sebenaranya, berterus terang, tidak berbohong.

5. Menyumbang (donating) Yaitu memberikan sumbangan, bantuan
6. Deramawan (generosity) Yaitu orang yang suka beramal, pemurah hati

7. Memperhatikan hak dan kesejahteraan orang lain Yaitu peduli atau ikut menjaga ketenangan, ketentraman, dan keselamatan orang lain

8. Punya kepedulian terhadap orang lain Yaitu kita merespon setiap kejadian yang terjadi di sekitar kita, mengambil tindakan.

Staub (1978) mengkategorikan faktor-faktor yang menyebabkan munculnya perilaku prososial ke dalam:

\section{The Situation}

Pengaruh sosial merupakan elemen yang sangat penting dari sebuah situasi. Orang-orang saling memberi pengaruh yang kuat satu sama lain. Salah satu unsur dari faktor situasi ini adalah sifat stimulus untuk perilaku prososial. Stimulus tersebut dapat berbeda pada beberapa dimensi. Unsur lainnya dari faktor ini adalah sifat dari kondisi di sekitar stimulus.

\section{Temporary States of Potential Helpers}

Faktor lain yang mempengaruhi perilaku prososial adalah bagaimana perasaan orang-orang yang berada dalam posisi untuk membantu melihat orang lain yang membutuhkan bantuan. Apakah mereka merasa baik atau buruk, kompeten atau tidak kompeten. Apakah sesaat harga diri mereka tinggi atau rendah. Apakah perhatian dan kepedulian mereka sangat terfokus pada diri mereka sendiri, atau mereka "bebas" untuk mengurus orang lain.

\section{Relationship to Potential Recipients of} Help

Hubungan seseorang dengan orang lain mungkin sangat penting dalam menentukan apakah seseorang tersebut akan membantunya. Mempertimbangkan apakah ada hubungan timbal balik atau hubungan yang saling menguntungkan pada masing-masing pihak atau tidak. 


\section{Personality Characteristics}

Segala jenis karakteristik kepribadian adalah penting dalam menentukan perilaku prososial, terutama yang dihubungkan dengan faktor situasi. Selain dari faktor situasi, orang-orang cukup sering mencari kesempatan untuk terlibat dalam tindakan prososial ini. Faktor penentu perilaku ini juga penting untuk dipertimbangkan.

\section{Psychological Processes}

Pemahaman kita mengenai penentuan perilaku sosial secara positif, kemampuan kita untuk memprediksi perilaku tersebut, dan kapasitas kita untuk menerapkan praktik sosialisasi yang akan mendorong keinginan orang lain untuk berperilaku prososial, apabila kita tahu mengapa pada kondisi tertentu seseorang akan atau tidak akan (kurang) berperilaku prososial.

\section{METODE}

Penelitian tindakan kelas dilaksanakan di TK PGRI Langkap Kecamatan Burneh, Kabupaten Bangkalan, dalam kurun waktu kurang lebih dua Minggu, yakni pada tanggal 22 Mei - 3 Juni pukul 07.00 sampai pukul $11.00 \mathrm{WIB}$.

Penelitian ini menggunakan jenis
Pendekatan Penelitian Tindakan Kelas
(Classroom Action Research), menurut Wina
Sanjaya yang menyertakan pola penelitian
tindakan kelas dibedakan menjadi tiga bentuk,
yaitu:(1) Pola Guru Peneliti, (2) Pola
Kolaboratif, (3) Pola Penelitian Terintegrasi.
Dalam penelitian ini peneliti menggunakan
pola kolaboratif, yaitu penelitian yang
melibatkan beberapa pihak baik guru, kepala
sekolah, dosen, maupun mahasiswa. Penelitian
kolaboratif, pihak yang melakukan tindakan
adalah guru itu sendiri, sedangkan yang
diminta melakukan pengamatan terhadap
berlangsungnya proses tindakan adalah
peneliti, bukan guru yang sedang melakukan
tindakan. Penelitian ini guru sebagai pengajar
dan peneliti bertindak sebagai pengamat.

Penelitian ini menggunakan jenis Pendekatan Penelitian Tindakan Kelas (Classroom Action Research), menurut Wina Sanjaya yang menyertakan pola penelitian tindakan kelas dibedakan menjadi tiga bentuk, yaitu:(1) Pola Guru Peneliti, (2) Pola Kolaboratif, (3) Pola Penelitian Terintegrasi. Dalam penelitian ini peneliti menggunakan sekolah, dosen, maupun ma kolaboratif, pihak yang melakukan tindakan adalah guru itu sendiri, sedangkan yang diminta melakukan pengamatan terhadap berlangsungnya proses tindakan adalah peneliti, bukan guru yang sedang melakukan dan peneliti bertindak sebagai pengamat.
Penelitian ini merupakan cara yang strategis untuk memperbaiki layanan kependidikan yang harus dilaksanakan dalam konteks pembelajaran dikelas dan peningkatan kualitas program sekolah secara keseluruhan. Oleh karena itu semua kegiatan selalu diamati, kemudian direfleksi dengan harapan dapat meningkatkan kualitas pembelajaran.

\section{Prosedur Penelitian Tindakan}

Penelitian tindakan kelas ini dilaksanakan dengan mengacu pada penelitian model Kemmis Taggart, dimana pada tahapantahapan ini berlangsung secara berulang-ulang, sampai tujuan penelitian tercapai. Adapun rancangan penelitian dalam pelaksanaan siklus I sebagai berikut :

\section{Perencanaan}

Rencana tindakan yang akan dilakukan untuk meningkatkan perilaku prososial pada anak usia 4-5 tahun melalui kegiatan Outbond fun Estafet ini dengan rincian tahap perencanaan adalah sebagai berikut:

a. Melakukan pertemuan dengan guru kelas untuk membicarakan persiapan kegiatan pembelajaran peningkatan kemampuan prososial anak melalui media mencocok gambar.

b. Mempersiapkan instrumen lembar observasi dan dokumentasi.

c. Mempersiapkan peralatan yang dibutuhkan untuk pelaksanaan proses pembelajaran.

d. Koordinasi dengan guru sebagai praktisi penelitian tentang tindakan yang harus dilakukan saat pembelajaran sesuai dengan rencana pembelajaran.

\section{Pelaksanaan}

Tindakan berisi tentang perlakuan guru di dalam kelas. Dalam penelitian ini menggunakan model kolaboratif, oleh karena itu guru kelas sebagai 
pengajar dalam proses pembelajaran dan peneliti sebagai pengamat atau observer. Pada siklus I dilakukan satu pertemuan dan setiap pertemuan dilakukan sesuai dengan jadwal yang ada disekolah selama 45 menit. Adapun rincian dari dari langkah-langkah pembelajaran adalah sebagai berikut:

a. Langkah 1 : Menyiapkan alat-alat yang akan digunakan dikegiatan outbond

b. Langkah 2 : Guru kemudian membagi dua kelompok yang tiap kelompok terdiri dari lima anak agar permainan/kegiatan ini berjalan dengan lancar.

c. Langkah 3 : Kegiatan pertama yaitu anak harus bersiap diri menjaga tempat asal kelereng kemudian anak berlari melintasi rintangan jejak kaki setelah itu anak menghampiri temannya yang menjaga jejak kaki untuk mengumpulkan kelereng sebanyak-banyaknya kedalam botol topi untuk dimasukkan kedalam bak di puncak akhir/finish.

d. Langkah 4 : Hasil dari kegiatan ini, anak mampu mengumpulkan kelereng sebanyak-banyaknya ditempat yang sudah disediakan oleh guru (Adu banyak mengumpulkan kelereng).

\section{Pengamatan (Observasi)}

Pengamatan dilakukan selama proses belajar mengajar berlangsung dengan menggunakan lembar observasi yang telah dibuat. Dalam penelitian ini guru sebagai pengajar dan peneliti sebagai pengamat selama proses tindakan.. Selain itu peneliti juga menggunakan alat bantu dokumentasi berupa kamera yang akan menunjukkan bukti konkret selama kegiatan berlangsung.

\section{Refleksi}

Data yang diperoleh dari peneliti dari lembar instrumen pengamatan selanjutnya didiskusikan dengan guru (kolaborator) sedangkan guru menyampaikan hasil evaluasi dari tindakan yang dilakukan dan peneliti menyampaikan hasil dari pengamatan. Diskusi dilakukan untuk mengevaluasi dari tindakan yang telah dilakukan. Refleksi dilakukan apabila hasil evaluasi terjadi permasalahan dari pelaksanaan tindakan atau hasil yang dicapai tidak mencapai indikator yang telah ditetapkan maka peneliti dan guru (kolaborator) bersama-sama mencari solusi untuk memecahkan permasalahan yang ada. Solusi yang dihasilkan merupakan perbaikan yang dijadikan pedoman untuk pelaksanaan tindakan selanjutnya yang dilakukan dalam bentuk tindakan siklus II.

Rencana tindakan yang akan dilakukan untuk meningkatkan perilaku prososial pada anak usia 4-5 tahun melalui kegiatan Outbond fun Estafet ini dengan rincian tahap perencanaan dalam siklus I1 adalah Peneliti Melakukan persiapan kegiatan pembelajaran peningkatan kemampuan prososial anak melalui kegiatan outbond fun estafet. Dan penambahan rintangan ditengahtengah kegiatan outbond fun estafet.

\section{Kriteria Keberhasilan Tindakan}

1. Penggunaan kegiatan bermain kertas ajaib dinyatakan dapat meningkatkan kemampuan perilaku prososial pada anak usia 4-5 tahun, apabila minimal $80 \%$ dari jumlah siswa mampu menunjukkan 3 indikator yang dipersyaratkan. Dengan kata lain,dapat menunjukkan keberhasilan pada kategori Berkembang Sesuai Harapan minimal $80 \%$ 
2. Penggunaan kegiatan Outbond Fun Estafet dinyatakan dapat meningkatkan kemampuan perilaku prososial pada anak usia 4-5 tahun, jika minimal $80 \%$ dari jumlah siswanya mendapat nilai diatas 70 .

Sumber data dalam penelitian adalah subjek dari mana data dapat diperoleh. Sumber data yang digunakan dalam penelitian ini adalah sumber data primer dan sekunder (Arikunto, 2006).

\section{Data Primer}

Merupakan data yang diperoleh secara langsung dari objek yang diteliti baik dari pribadi (responden) maupun dari suatu perusahaan yang mengolah data untuk keperluan penelitian, seperti dengan cara melakukan wawancara secara langsung dengan pihak-pihak yang berhubungan dengan penelitian yang dilakukan (Sugiyono, 2012).

Peneliti mengambil data primer dari sumber-sumber penelitian yakni yang pertama anak, karena sang anak akan menjadi sorotan atau obyek utama sebagai dampak dari adanya perlakuan yang dilakukan kepadanya. Kedua yakni guru kelas sebagai pelaksana dalam penelitian tindakan kelas ini.

\section{Data Sekunder}

Sumber sekunder adalah: "Sumber yang tidak langsung memberikan data kepada pengumpul data, misalnya lewat orang lain atau dokumen".Data yang digunakan yaitu berupa hasil catatan observasi yang dilakukan oleh peneliti ketika observasi ditempat penelitian, kemudian dokumentasi foto dari hasil pengamatan sebagai sumber data yang setiap momen untuk diabadikan

Secara umum terdapat empat macam teknik pengumpulan data, yaitu Observasi, wawancara, dokumentasi, dan gabungan/triangulasi. Berikut penjelasannya.

a. Observasi

Peneliti menggunakan jenis Observasi partisipatif dan tidak terstruktur karena dalam pengamatan peneliti terlibat langsung dalam keseharian sang Anak ketika menghadapi ayahnya dan dari pengamatan ini lah peneliti mampu mengambil data secara langsung ditempat yang menjadi latar penelitian. Mengenai observasi yang tidak terstruktur peneliti gunakan ketika pada saat penelitian ada kejadian-kejadian yang perlu dicatat tanpa berpanduan pada sistematika yang dibuat, bisa dibilang ini bersifat insidental tanpa persiapan.

\section{b. Dokumentasi}

Dokumentasi penelitian ini merupakan pengambilan gambar oleh peneliti untuk memperkuat hasil penelitian.

Analisis data menurut Patton, proses mengatur urutan data, mengorganisasikannya ke dalam suatu pola, kategorisasi, dan satuan uraian dasar (Moleong, 2008). Analisis data dalam penelitian kualitatif, dilakukan pada saat pengumpulan data berlangsung, dan setalah selesai pengumpulan data dalam periode tertentu. Pada saat wawancara peneliti sudah melakukan analisis terhadap jawaban yang diwawancarai.

Jawaban yang diwawancarai setelah dianalisis terasa belum memuaskan, maka peneliti akan melanjutkan pertanyaan lagi, sampai tahap tertentu, diperolah data yang dianggap kredibel. Miles dan Huberman (1894) mengemukakan bahwa aktifitas dalam analisis data kuantitatif dan kualitatif dilakukan secara interaktif dan berlangsung secara terus menerus sampai tuntas, sehinga datanya sudah jenuh. 
Untuk analisis data kuantitatif maka data yang dicari dan dikaji yakni analisis statistika sederhana mencari mean. Mean adalah nilai rata-rata dari semua data.

Rumus menghitung mean atau rata-rata:

$$
\begin{aligned}
& \overline{\mathrm{X}}=\frac{x_{1}+x_{2}+x_{3}+\ldots+x_{n} n}{\mathrm{n}} \\
& \overline{\mathrm{X}}=\frac{\sum x_{i}}{n} \text { atau } \frac{\sum \mathrm{f} x_{\mathrm{i}}}{f}
\end{aligned}
$$

Aktivitas dalam analisis data kualitatif yaitu reduksi data, display data, kesimpulan.

Langkah-langkah dalam analisis data kualitatif yang peneliti gunakan dalam penelitian ini adalah :

a. Pengumpulan data. Data penelitian diperoleh dengan menggunakan teknik wawancara mendalam (indepth interview). Dalam penelitian ini data yang akan diambil adalah data-data yang berkaitan dengan pengelolaan dan hambatan-hambatan yang muncul dalam meningkatkan perilaku prososial anak melalui kegiatan Outbond Fun Estafet.

b. Reduksi data. Reduksi data diartikan sebagai proses pemilihan dan pemusatan pada data yang relevan dengan permasalahan penelitian. Data-data yang direduksi adalah data-data dari hasil wawancara mendalam yang di dapat dari lapangan. Setelah dibaca, dipelajari, ditelaah, selanjutnya diambil data yang memiliki relevansi dengan penelitian dan disesuaikan dengan kebutuhan penelitian ini. Data yang diambil adalah data yang berhubungan dengan meningkatkan kecerdasan matematika awal menggunakan kegiatan bermain kartu ajaib

c. Penyajian data merupakan upaya penyusunan, pengumpulan informasi ke dalam suatu metrik atau konfigurasi sehingga mudah untuk dipahami.
Penyusunan semacam ini memungkinkan adanya penarikan kesimpulan dan pengambilan tindakan. Penyajian data yang sederhana dan mudah untuk dipahami adalah cara utama untuk menganalisa data deskriptif yang valid. Penyajian data yang dilakukan peneliti adalah mengenai gambaran dalam meningkatkan perilaku prososial anak melalui kegiatan Outbond Fun Estafet.

d. Menarik kesimpulan. Berdasarkan pengumpulan data, peneliti mulai mencari makna dari data-data yang terkumpul. Selanjutnya peneliti mencari arti dan penjelasannya, kemudian menyusun pola-pola hubungan tertentu ke dalam satu satuan informasi yang mudah dipahami dan ditafsirkan sehingga dapat menarik kesimpulan sebagai jawaban dari permasalahan yang ada. Kesimpulan yang akan ditulis peneliti adalah mengenai meningkatkan meningkatkan perilaku prososial anak melalui kegiatan Outbond Fun Estafet.

\section{HASIL DAN PEMBAHASAN}

Penelitian di lakukan di TK PGRI 1 Langkap kelompok Usia 4-5 tahun. Obsever Pertama kali datang ke sekolah meminta izin untuk observasi. Kegiatan yang dilakukan peneliti mengamati keadaan sekolah. Kemudian mengikuti kegiatan di dalam kelas untuk mengikuti pembelejaran. Di kelas kelompok usia 4-5 tahun dipegang oleh satu guru pada waktu itu tema pembelajaran yakni rekreasi dengan kegiatan mewarnai perlengkapan meminjam crayon jika bukan teman baik maka tidak akan dipinjami. Lalu suka berebut dengan temannya jika sedang pinjam meminjam mainan. Dari kegiatan ini peneliti menemukan permasalahan yakni banyak anak-anak yang masih memiliki sikap invidual dan belum berperilaku prososial dengan baik. 


\section{Deskripsi Pelaksanaan siklus I}

Proses pelaksanaan tindakan pada siklus pertama adalah peningkatan perilaku Prososial anak melalui kegiatan bermain Outbond fun estafet.. Langkah-langkah dalam proses penelitian ini terdiri atas perencanaan, pelaksanaan, observasi, dan refleksi yakni sebagai berikut:

\section{Perencanaan}

Rencana tindakan yang akan dilakukan untuk meningkatkan perilaku prososial pada anak usia 4-5 tahun melalui kegiatan Outbond fun Estafet ini dengan rincian tahap perencanaan dalam siklus I adalah sebagai berikut : Melakukan pertemuan dengan guru kelas untuk membicarakan persiapan kegiatan pembelajaran peningkatan kemampuan prososial anak melalui kegiatan outbond fun estafet. Kemudian mempersiapkan instrumen lembar observasi dan dokumentasi. Mempersiapkan peralatan yang dibutuhkan untuk pelaksanaan proses pembelajaran. Koordinasi dengan guru sebagai praktisi penelitian tentang tindakan yang harus dilakukan saat pembelajaran sesuai dengan rencana pembelajaran. Lembar observasi digunakan untuk mencatat hasil pengamatan selama penelitian berlangsung. Kemampuan berprilaku prososial anak ditentukan dengan skor yaitu skor 4 untuk anak yang berkembang dengan sangat baik, skor 3 untuk anak yang berkembang cukup baik, dan skor 2 untuk anak yang kurang baik, skor 1 anak yang kurang.

\section{Pelaksanaan.}

Tindakan berisi tentang perlakuan guru di dalam kelas. Dalam penelitian ini menggunakan model kolaboratif, oleh karena itu guru kelas sebagai pengajar dalam proses pembelajaran dan peneliti sebagai pengamat atau observer.
Pada siklus I dilakukan satu pertemuan dan setiap pertemuan dilakukan sesuai dengan jadwal yang ada disekolah selama 45 menit. Adapun rincian dari dari langkah-langkah pembelajaran adalah sebagai berikut: Menyiapkan alat-alat yang akan digunakan dikegiatan outbond, Guru kemudian membagi dua kelompok yang tiap kelompok terdiri dari lima anak agar permainan/kegiatan ini berjalan dengan lancar.

Kegiatan pertama yaitu anak harus bersiap diri menjaga tempat asal kelereng kemudian anak berlari melintasi rintangan jejak kaki setelah itu anak menghampiri temannya yang menjaga jejak kaki untuk mengumpulkan kelereng sebanyakbanyaknya kedalam botol topi untuk dimasukkan kedalam bak di puncak akhir/finish. Hasil dari kegiatan ini, anak mampu mengumpulkan kelereng sebanyak-banyaknya ditempat yang sudah disediakan oleh guru (Adu banyak mengumpulkan kelereng).

\section{Observasi.}

Pengamatan dilakukan selama proses belajar mengajar berlangsung dengan menggunakan lembar observasi yang telah dibuat. Dalam penelitian ini guru sebagai pengajar dan peneliti sebagai pengamat selama proses tindakan.. Selain itu peneliti juga menggunakan alat bantu dokumentasi berupa kamera yang akan menunjukkan bukti konkret selama kegiatan berlangsung.

\section{Refleksi}

Refleksi dilakukan saat peneliti beserta guru sudah melakukan siklus I. Ada beberapa hal refleksi pada siklus I, antara lain sebagai berikut:

a) Ada anak yang masih terlihat kesulitan dalam mempraktikkan 
kegiatan fun estafet ini, seperti menempatkan kelereng pada teman yang satu dengan menggunakan pipa dari aqua.

b) Anak juga masih memperebutkan bagian pos yang sudah dibagi oleh guru sebelumnya sehingga ini membuat waktu menjadi mundur untuk memulai permainan

c) Tingkat kerjasama juga kurang terlihat mereka masih belum bisa membaur antar sesama, ada saja yang masih berebut ingin satu kelompok dengan teman yang disukainya

d) Mereka masih dikatakan belum terbiasan dengan permainan outbond tapi antusiasme dan permainan berjalan tertib seuai pelaksanaan sudah mendapat nilai plus dari peneliti

Setelah dilakukannya tindakan pada siklus I maka peneliti dan guru memberikan assesmen terhadap perilaku prososial anak. Hal ini dilakukan untuk mengetahui skor pada tindakan siklus I terhadap prososial anak. Hasil assesmen setelah pemberian tindakan siklus I adalah sebagai berikut :

\section{Tabel 1}

Assesmen Perilaku Prososial Anak pada Siklus I

\begin{tabular}{|c|c|c|c|c|c|}
\hline \multirow{2}{*}{$\begin{array}{c}\text { Nama } \\
\text { Siswa }\end{array}$} & \multicolumn{2}{|c|}{ Rata-Rata } & $\begin{array}{c}\text { Rata- } \\
\text { Rata }\end{array}$ & \multirow{2}{*}{ \% } & \multirow{2}{*}{ Ket } \\
\cline { 2 - 5 } & $\begin{array}{c}\text { Obs } \\
\mathbf{1}\end{array}$ & $\begin{array}{c}\text { Obs } \\
\mathbf{2}\end{array}$ & $\begin{array}{c}\text { Siklus } \\
\mathbf{1}\end{array}$ & \multirow{2}{*}{4} & \\
\cline { 2 - 5 } RZ & 30 & 29 & 29.50 & 49.17 & MB \\
\hline FN & 30 & 32 & 31.00 & 51.67 & MB \\
\hline CP & 27 & 28.5 & 27.50 & 45.83 & MB \\
\hline BG & 30 & 28.5 & 29.25 & 48.75 & MB \\
\hline KR & 28 & 26.5 & 27.25 & 45.42 & MB \\
\hline AM & 33 & 33.5 & 33.25 & 55.42 & MB \\
\hline JW & 30 & 30 & 29.75 & 49.58 & MB \\
\hline AN & 27 & 28.5 & 27.75 & 46.25 & MB \\
\hline MW & 31 & 32.5 & 31.75 & 52.92 & MB \\
\hline VT & 29 & 31 & 29.75 & 49.58 & MB \\
\hline
\end{tabular}

Dapat dilihat dari tabel diatas hasil presentase anak bahwa diketahui jika semua anak masih dalam tahap mulai berkembang dalam meningkatkan perilaku prososial, anak mendapat rata-rata tertinggi adalah 33,25 dan dengan rata-rata terendah 27.25 sehingga dari hasil yang sudah diketahui ini perlulah perbaikan dan keberlanjutan penelitian kembali pada tahap siklus II dalam kegiatan outbond fun estafet untuk meningkatkan perilaku prososial, sedangkan perilaku prososial anak siklus 1 yaitu seluruh anak masih dalam tahap mulai berkembang dan anak yang mendapat rata-rata tertinggi adalah 33,25 atau mencapai persentase $55.42 \%$ dan untuk rata-rata terendah anak mendapatkan 27.25 setara nilai persentase $45.42 \%$. jadi masih perlu tindakan kembali, karena skor anak belum mencapai $80 \%$ dari syarat criteria keabsahan data yang sudah ditentukan. Jadi penelitian tindakan ini akan di lanjutkan ke tahap siklus II.

\section{Deskripsi Pelaksanaan Siklus II}

Proses pelaksanaan tindakan pada siklus kedua dilakukan karena pada siklus I dirasa belum mencukupi data mengenai peningkatan prososial. Langkah-langkah dalam proses penelitian ini terdiri atas perencanaan, pelaksanaan, observasi, dan refleksi. Berikut adalah deskrisi dari langkah-langkah tersebut :

\section{Perencanaan}

Rencana tindakan yang akan dilakukan untuk meningkatkan perilaku prososial pada anak usia 4-5 tahun melalui kegiatan Outbond fun Estafet ini dengan rincian tahap perencanaan dalam siklus I1 adalah sebagai berikut : Peneliti Melakukan persiapan kegiatan pembelajaran peningkatan kemampuan prososial anak melalui kegiatan outbond fun estafet. Dan penambahan rintangan ditengah-tengah kegiatan outbond fun estafet. Kemudian mempersiapkan instrumen lembar observasi dan dokumentasi. Mempersiapkan peralatan yang dibutuhkan untuk pelaksanaan proses pembelajaran. Koordinasi dengan guru sebagai praktisi penelitian tentang tindakan yang harus dilakukan saat 
pembelajaran sesuai dengan rencana pembelajaran.

Lembar observasi digunakan untuk mencatat hasil pengamatan selama penelitian berlangsung. Kemampuan berprilaku prososial anak ditentukan dengan skor yaitu skor 4 untuk anak yang berkembang dengan sangat baik, skor 3 untuk anak yang berkembang cukup baik, dan skor 2 untuk anak yang kurang baik, skor 1 anak yang kurang.

\section{Pelaksanaan}

Siklus 2 dilakukan satu pertemuan dan setiap pertemuan dilakukan sesuai dengan jadwal yang ada disekolah selama 45 menit. Adapun rincian dari dari langkah-langkah pembelajaran adalah sebagai berikut: Menyiapkan alat-alat yang akan digunakan dikegiatan outbond, Guru kemudian membagi dua kelompok yang tiap kelompok terdiri dari lima anak agar permainan/kegiatan ini berjalan dengan lancar.

Kegiatan pertama yaitu anak harus bersiap diri menjaga tempat asal kelereng kemudian anak berlari melintasi rintangan jejak kaki setelah itu anak menghampiri temannya yang menjaga jejak kaki untuk mengumpulkan kelereng sebanyakbanyaknya kedalam botol topi untuk dimasukkan kedalam bak di puncak akhir/finish namun diberikan waktu 5 menit untuk anak menyelesaikannya dan ditambahi rintangan ringan ditengahtengah kegiatan outbond tersebut. Hasil dari kegiatan ini, anak mampu mengumpulkan kelereng sebanyakbanyaknya ditempat yang sudah disediakan oleh guru (yang paling banyak mengumpulkan kelereng).

\section{Observasi}

Pengamatan dilakukan selama proses belajar mengajar berlangsung dengan menggunakan lembar observasi yang telah dibuat. Dalam penelitian ini guru sebagai pengajar dan peneliti sebagai pengamat selama proses tindakan. Selain itu peneliti juga menggunakan alat bantu dokumentasi berupa kamera yang akan menunjukkan bukti konkrit selama kegiatan outbond berlangsung.

\section{Refleksi}

Refleksi dilakukan saat peneliti beserta guru sudah melakukan siklus II. Ada beberapa hal refleksi pada siklus I, antara lain sebagai berikut:

a) Disiklus kedua anak sudah terlihat baik dan benar dalam mempraktikkan kegiatan fun estafet ini.

b) Anak sudah tidak memperebutkan bagian pos yang sudah dibagi oleh guru sebelumnya sehingga membuat kegiatan fun estafet berjalan dengan tepat waktu daan berjalan sesuai rencana.

c) Tingkat kerjasama mereka sudah meningkat terlihat ketika mereka melakukan kegiatan dan ada salah satu anak yang belum mengerti kemudian salah satu anak memberikan arahan yang tepat.

d) Antusiasme mereka sangat nampak dan permainan berjalan tertib seuai pelaksanaan sudah mendapat nilai plus dari peneliti sehingga pada siklus kedua ini sudah bisa dikatakan sepenuhnya berhasil dan anak menglami peningkatan.

\section{Assesmen Akhir Siklus II}

Setelah dilakukannya tindakan pada siklus I maka peneliti dan guru memberikan assesmen terhadap perilaku prososial anak pada siklus II. Hal ini dilakukan untuk mengetahui skor pada tindakan siklus II terhadap prososial anak. Hasil assesmen 
setelah pemberian tindakan siklus II adalah sebagai berikut :

\section{Tabel 2}

Assesmen Perilaku Prososial Anak pada Siklus II

\begin{tabular}{|c|c|c|c|c|c|}
\hline \multirow{2}{*}{$\begin{array}{l}\text { Nama } \\
\text { Siswa }\end{array}$} & \multicolumn{2}{|c|}{ Rata-Rata } & \multirow{2}{*}{$\begin{array}{c}\text { Rata-Rata } \\
\text { Siklus } 2\end{array}$} & \multirow[b]{2}{*}{$\%$} & \multirow[b]{2}{*}{ Ket } \\
\hline & $\begin{array}{c}\text { Obs } \\
1 \\
\end{array}$ & $\begin{array}{c}\text { Obs } \\
2\end{array}$ & & & \\
\hline $\mathrm{RZ}$ & 50 & 53 & 51.50 & 85.83 & BSB \\
\hline FN & 51 & 50 & 50.50 & 84.17 & BSB \\
\hline $\mathrm{CP}$ & 50 & 53 & 51.50 & 85.83 & BSB \\
\hline BG & 48 & 49 & 48.25 & 80.42 & $\mathrm{BSH}$ \\
\hline KR & 49 & 51 & 50.00 & 83.33 & BSB \\
\hline $\mathrm{AM}$ & 51 & 52.5 & 51.75 & 86.25 & BSB \\
\hline JW & 48 & 47.5 & 47.75 & 79.58 & $\mathrm{BSH}$ \\
\hline AN & 49 & 49.5 & 49.25 & 82.08 & BSB \\
\hline MW & 49 & 48.5 & 48.50 & 80.83 & $\mathrm{BSH}$ \\
\hline $\mathrm{VT}$ & 51 & 52 & 51.25 & 85.42 & BSB \\
\hline
\end{tabular}

Berdasarkan hasil tabel diatas diperoleh data tentang perilaku prososial anak pada siklus II yaitu seluruh anak mengalami peningkatan yang sangat drastis, aspek yang tercapai melebihi angka rata-rata pada umumnya. Berdasarkan criteria keberhasilan tindakan jadi hampir semua anak $80 \%$ sudah berkembang sesuai harapan (BSH). Pada perhitungan rata-rata sekolah mendapat ratarata tertinggi adalah 51,75 yang menunjukkan bahwa $86.25 \%$ prosentase anak telah tercapai dengan baik dan dilain pihak dengan rata-rata terendah 47.75 dengan jumah presentase $79.58 \%$. jadi dapat disimpulakn bahwa pada siklus II ini rata-rata anak sudah bisa memaknai dirinya sendiri bagimana berperilaku prososial sesuai indikator yang sudah dibuat.

\section{Pembahasan}

Indikator keberhasilan tindakan dalam penelitian ini adalah terjadinya peningkatan perilaku prososial anak. Hasil penelitian ini menunjukkan bahwa perilaku prososial anak meningkat melalui kegiatan bermain outbond fun estafet, dengan metode bermain yang dibentuk secara kelompok maka akan membangun kerjasama dalam setiap individu untuk saling berempati dan peduli terhadap anggota kelompoknya. Hal ini dapat dilihat juga dari peningkatan perilaku prososial anak ketika diberikan perlakuan atau tindakan kepada anak. Pada assesmen awal pada siklus 1 mendapat persentase sebesar 55.42\%. sedangkan di siklus II menjadi $86.25 \%$.

Seperti yang sudah disepakati oleh peneliti dan kolaborator bahwa indikator keberhasilan tindakan sebesar $80 \%$. Akan tetapi jika belum mencapai persentase rata-rata yang sudah ditentukan makan akan dilanjutkan ke siklus II. Lebih rinci lagi peneliti akan merinci bahwa secara kualitatif dari siklus 1 dan siklus II anak mendapat skor tertinggi diperoleh oleh Am, sedangkan anak yang memperoleh skor terendah yaitu Jw. Dapat dilihat dari keseharian Am memang tidak heran ia mendapatkan skor tertinggi, dari latar belakang keluarga Am ini anak pertama dan mempunyai satu adik sehingga dari kecil ia sudah harus mandiri apalagi dengan seorang ayahnya yang menjadi guru SMP, jadi kemana-mana Am selalu ikut dengan ayahnya jadi ada sosok ayah yang patut untuk dicontoh sehingga perkembangan sosialnya juga baik.

Hal ini dipengaruhi oleh lingkungan sekitarnya juga bahwa hubungan sosialnya memang kurang, dari orang tua juga masih tidak mau meninggalkannya ketika sekolah sehingga Jw merasa tergantung dengan ibunya. Dan hanya mau bersosialisasi dengan temannya yang sebangku. Hal tersebut membuat Jw menjadi pemalu dan untuk bersosialisasi dengan lingkungan ia masih merasa belum bisa terbuka sesame teman maupun orang-orang disekitarnya.

Anak usia dini yaitu kajian dari sudut pandang pedagogik, menurut hoogveld dalam Sadullah (2010: 2) pedagogis merupakan ilmu yang mempelajari masalah membimbing anak ke arah tujuan tertentu yaitu supaya anak mampu untuk menyelesaikan tugas hidupnya. Berdasarkan hasil penelitian bahwa melalui kegiatan bermain Outbond fun estafet dapat 
meningkatkan perilaku prososial anak karena anak akan berinteraksi secara positif antar anak dan sikap penerimaan dengan lingkungan sekitar. Kajian dari sudut pandang perkembangan sosial menurut Erikson dalam Papalia dan old (2008) yakni sikap mulai lepas dari ikatan orang tua, anak dapat bergerak bebas dan berinteraksi dengan lingkungannya. Sehingga dalam permainan ini anak bisa saling bekerjasama dengan sesama dan belajar berinteraksi dengan lingkungan barunya.

\section{SIMPULAN}

\begin{abstract}
Berdasarkan hasil penelitian dan pembahasan dapat disimpulkan bahwa Kegiatan outbound Fun Estafet dapat meningkatkan kemapuan sosial emosional anak usia dini 4-5 tahun di TK PGRI Burneh Bangkalan. Hasil pelaksanaan pembelajaran dengan media Kegiatan outbound Fun Estafet dapat dilihat pada tingkat keberhasilan kegiatan yang dilakukan pada setiap tahapan siklus yang mengalami peningkatan.
\end{abstract}

Kondisi awal kemampuan sosial emosional anak sebelum diberikan tindakan yang masuk dalam kriteria skor tiga ada $31 \%$. Pada siklus I guru menggunakan Kegiatan outbound Fun Estafet dalam kegiatan tersebut diberikan cotoh perbuatan yang seharusnya dilakukan oleh anak, setelah itu anak mempraktikkan kegiatan seperti yang telah dicontohkan yaitu anak mau meminjamkan miliknya, anak mau berbagi dengan teman, dan anak saling membantu sesama teman. Pada siklus I anak yang memperoleh skor 3 terdapat $55,25 \%$, pada siklus II peningkatan kemampuan sosial emosional menjadi 86,20\%.

Proses pelaksanaan atau langkahlangkah kegiatan belajar mengajar dengan menggunakan Kegiatan outbound Fun Estafet yaitu terlebih dahulu guru melakukan apersepsi. Guru menunjukkan atua mengenalkan bentuk dari kegiatan dan memeberikan contoh sebelum anak disuruh melakukan kegiatan tersebut. Setelah selesai melihat contoh kegiatan kemudian anak dibagi menjadi berkelompok untuk mempraktikkan kegiatan seperti yang telah dicontohkan

\section{Saran}

Berdasarkan pelaksanaan Obsevasi kegiatan outbound Fun Estafet untuk meningkatkan kemampuan sosial emosional, maka ada saran untuk meningkatkan kemampuan sosial emosional yaitu:

1. Bagi Sekolah

Hendaknya sekolah menggunakan kegiatan outbound Fun Estafet dalam meningkatkan kemampuan sosial emosional anak.

2. Bagi Guru

Guru membuat kegiatan belajar yang menarik dengan menggunakan kegiatan outbound Fun Estafet agar anak lebih bersemangat lagi ketika proses pembelajaran berlangsung.

3. Bagi Anak

Disarankan kepada anak pada setiap pembelajaran sosial emosional mengikuti dengan serius penjelasanpenjelasan yang diberikan oleh guru dengan menggunakan kegiatan outbound Fun Estafet ini.

\section{DAFTAR PUSTAKA}

\section{Buku}

Arikunto,dkk. 2008. Penelitian Tindakan Kelas. Jakarta:PT Bumi Aksara.

Dayaksini, T., dan Hudaniah. 2003. Psikologi Sosial. Malang: UMM.

Hurlock, E. 1978. Perkembangan Anak Jilid 1 ed.6. Jakarta: Erlangga.

Hurlock, E. 2006. Psikologi Perkembangan. Jakarta: Erlangga. 
Moleong, L. J. 2008. Metodologi Penelitian Kualitatif. Bandung : PT. Remaja Rosdakarya.

Sanjaya, Wina. 2010. Penelitian Tindakan Kelas. Jakarta: Kencana Prenada Media Grup.

Shoimin, Aris. 2014. 68 Model Pembelajaran Kontekstual dan Penerapannya dalam $K B K$. Malang: Universitas Negeri Malang.

Sugiyono, 2012. Metodologi Penelitian Pendidikan. Bandung: Alfabeta.

Sujiani, Y. 2012. Konsep Dasar Pendidikan Anak Usia Dini. Jakarta : PT Indeks.

Totong, U. 2011. Pengaruh Outbond Traning Terhadap Peningkatan Rasa Percaya Diri Kepemimpinan dan Kerjasama Tim. Skripsi. Surakarta: Universitas Pembangunan, 2011.

Widiasworo, E. 2017. Strategi \& Metode Mengajar Siswa di Luar Kelas. Yogyakarta: Ar-ruzz Media.

Zaenal, A. 2013. Metodologi Penelitian Pendidikan. Yogyakarta: Diva Press. 